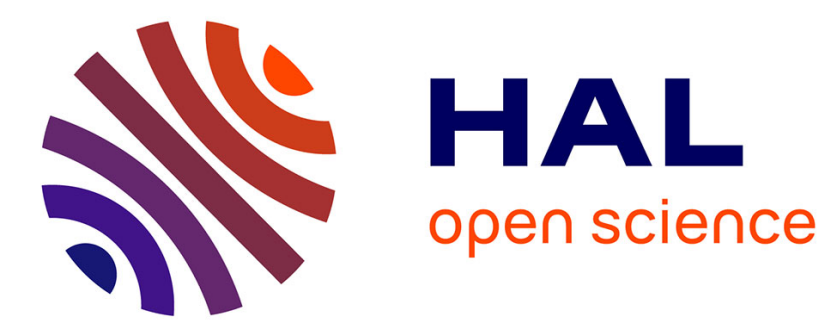

\title{
Preparation of flat gold terraces for protein chip developments
}

Céline Elie-Caille, Jean-Yves Rauch, Alain Rouleau, Wilfrid Boireau

\section{To cite this version:}

Céline Elie-Caille, Jean-Yves Rauch, Alain Rouleau, Wilfrid Boireau. Preparation of flat gold terraces for protein chip developments. Micro and Nano Letters, 2009, 4 (2), pp.88-94. hal-00447012

\section{HAL Id: hal-00447012 \\ https://hal.science/hal-00447012}

Submitted on 14 Jan 2010

HAL is a multi-disciplinary open access archive for the deposit and dissemination of scientific research documents, whether they are published or not. The documents may come from teaching and research institutions in France or abroad, or from public or private research centers.
L'archive ouverte pluridisciplinaire HAL, est destinée au dépôt et à la diffusion de documents scientifiques de niveau recherche, publiés ou non, émanant des établissements d'enseignement et de recherche français ou étrangers, des laboratoires publics ou privés. 


\title{
Preparation of flat gold terraces
}

\section{for protein chip developments}

\author{
Céline Elie-Caille*, Jean-Yves Rauch, Alain Rouleau* \& W. Boireau* \\ Institut FEMTO-ST, Université de Franche Comté, CNRS - 25044 Besançon cedex, France \\ *Clinical-Innovation Proteomic Platform (CLIPP)
}

Corresponding author: celine.caille@,clipproteomic.fr

Tel: +3381853922 ; fax: +3381853998

\begin{abstract}
A simply method to prepare flat gold terraces on mica for AFM biomolecular characterization is described. The procedure includes preheating of the substrate, a metal deposition followed by an annealing step, all of these steps lead at elevated temperature $\left(300\right.$ to $\left.420^{\circ} \mathrm{C}\right)$. This approach allowed to prepare large flat gold terraces $(200$ to $500 \mathrm{~nm})$, that constituted ideal substrates for visualization and characterization of self-assembly monolayer of biomolecules at the nanoscale. We illustrated this potential of characterization with the reconstitution of a protein monolayer.
\end{abstract}




\section{Introduction}

Repartition and orientation of immobilized proteins on bio-devices are very important to assure their high performance. There have been few methods to evaluate surface coverage, molecules repartition and even tridimensional structure and orientation of immobilized proteins. One of them is time-of-flight secondary ion mass spectrometry (TOF-SIMS) that is able to analyze upper surface of one layer of molecules ${ }^{1,2}$. Atomic force microscopy is one of the methods of choice to achieve the protein surface coverage, the biofilm homogeneity with a molecular resolution until protein structure, without any "denaturating" sample preparation or labeling ${ }^{3}$.

Gold surfaces provide convenient supports for a number of reasons. Gold is rather chemically inert to biomacromolecules; but, on the other hand, it is accessible to chemisorption via the formation of stable gold-thiol bonds. Based on that, a protein having a unique cystein, i.e. a unique sulfhydryl residue at the periphery of the 3D structure, will naturally self-assemble on

gold substrate. Bearing this sulfhydryl moiety, cytochrome b5 is able to perform direct selfassembly onto gold surface by chemisorption process leading to a packed and oriented self assembled monolayer (SAM) ${ }^{2}$

The classical way to prepare thin gold films is vacuum evaporation of gold onto glass, silicon or mica, at low pressure. This deposition method induces metal films presenting globular gold grains measuring 25 to $30 \mathrm{~nm}$ in diameter ${ }^{4}$. Such rough surfaces present limitations in resolution when gold immobilized biomolecules have to be imaged and characterized. Atomically flat gold substrates seem ideal to better characterize surface bound biomolecules using scanning microscopy methods. Mica substrate is often preferred as it provides a clean and highly flat surface. When gold is deposited on such an atomically flat surface, the metal 
film can be stripped from mica and used on this "mica-like face", The other possibility is to thermally anneal the gold covered mica since this method allows improving the flatness of the gold film. Nevertheless the first "stripping" method often needs the deposition of another layer on gold, in order to propose a new "support" to the gold stripped film. This method is moreover delicate to realize due to the stripping step of metal film in the case of a mechanical pealing. Stripping can be also obtained through a chemical treatment using THF. This last possibility presents also limitations especially in terms of surface contamination by mica flasks ${ }^{6}$.

We propose here a new method to prepare gold films presenting large flat terraces on mica. Our method is rapid, highly controlled in terms of pressure and temperature and limitation of surface contamination, since the whole process happens under a non-ruptured vacuum (substrate preheating, metal deposition and annealing). We present the relevancy of such a flat gold surface in the characterization of a protein monolayer specifically self-assembled on it. 


\section{Material and methods}

\subsection{Materials}

Pure 99,99\% gold metal and mica sheets (G250-1, from Agar Scientific) were used. Engineered cytochrome b5 was prepared as described in the reconstitution procedure. Octylglucopyranoside (OG) and dithiothreitol (DTT) were purchased from Sigma-Aldrich.

\subsection{Metal deposition and annealing run}

Gold thin films were deposited on mica substrates to prepare flat terraces, by electron beam evaporation in an Alliance Concept EVA450 vacuum system at a pressure of $4 * \times 10^{-6}$ mbar. Indeed, we wanted to obtain very thin grain size, in order to mimic the flat state of the mica's surface while realizing flat gold terraces. Before gold deposition run, the substrates were first heated at a stabilized temperature of $300^{\circ} \mathrm{C}$ for half an hour and then etched with argon ion beam powered by a hallow cathode of $3 \mathrm{~cm}$ diameter at a pressure of $3,6 \times 10^{-4}$ mbar. Positive argon ions were neutralized by flow rates of negative species before impact of the substrates. An Argon flow rate was $5 \mathrm{sccm}$ in cathode and neutralizer, and the pressure in the chamber was obtained by a high-speed turbo molecular pump Leybold of $12001 . \mathrm{min}^{-1}$ coupled with a primary rotative pump. Finally, evaporation was obtained by heating the pure $99,99 \%$ gold metal in a liner of graphite. In a first time, deposition was made on the shadow between liner and substrates until the right and regular speed rate control by an Inficon XTC2 quartz crystal was reached.

Gold was deposited either in one or two steps. For sample I, deposition of gold film has been made in two steps: first, $150 \mathrm{~nm}$ was deposited at a rate of $5 \mathrm{~nm} \cdot \mathrm{sec}^{-1}$ which will be reduced to $0.05 \mathrm{~nm} \cdot \mathrm{sec}^{-1}$ to achieve the thickness of $200 \mathrm{~nm}$. For samples II, III and IV, the gold films were obtained in one step at low gold deposition rate. 
For all samples, heating, etching and gold layer depositions were all realized at $300^{\circ} \mathrm{C}$. Samples I and II stayed in the same chamber for a run of $30 \mathrm{~min}$ and $8 \mathrm{~h}$ of annealing at $300^{\circ} \mathrm{C}$. Samples III, IV and V were annealed in another vacuum system at $2.5^{*} \times 10^{-6}$ mbar for $3 \mathrm{~h}, 20 \mathrm{~h}$ or $32 \mathrm{~h}$ at $420^{\circ} \mathrm{C}$ respectively. Sample VI was obtained after a classical gold deposition of $150 \mathrm{~nm}$ (without heating) followed by an annealing step of $20 \mathrm{~h}$ at $420^{\circ} \mathrm{C}$.

Table 1: Various conditions of gold deposition and annealing runs.

\begin{tabular}{|c|c|c|c|c|}
\hline $\begin{array}{l}\text { Sample } \\
\text { number }\end{array}$ & Heating parameters & $\begin{array}{l}\text { Etching at } 300^{\circ} \mathrm{C} \\
(\min )\end{array}$ & $\begin{array}{l}\text { Gold thickness and } \\
\text { deposition rate at } 300^{\circ} \mathrm{C}\end{array}$ & $\begin{array}{l}\text { Annealing } \\
\text { parameters }\end{array}$ \\
\hline I & \multirow{5}{*}{$30 \mathrm{~min}$ at $300^{\circ} \mathrm{C}$} & \multirow{5}{*}{$1 \mathrm{~min}$ at $3.6 .10^{-4} \mathrm{mbar}$} & $\begin{array}{l}150 \mathrm{~nm} \text { at } 5 \mathrm{nmsec}^{-1} \\
50 \mathrm{~nm} \text { at } 0.05 \mathrm{nmsec}^{-1}\end{array}$ & $30 \mathrm{~min}$ at $300^{\circ} \mathrm{C}$ \\
\hline II & & & $50 \mathrm{~nm}$ at $0.1 \mathrm{nmsec}^{-1}$ & $8 \mathrm{~h}$ at $300^{\circ} \mathrm{C}$ \\
\hline III & & & \multirow{4}{*}{$150 \mathrm{~nm}$ at $0.1 \mathrm{nmsec}^{-1}$} & $3 \mathrm{~h}$ at $420^{\circ} \mathrm{C}$ \\
\hline IV & & & & 20 h at $420^{\circ} \mathrm{C}$ \\
\hline $\mathrm{V}$ & & & & $32 \mathrm{~h}$ at $420^{\circ} \mathrm{C}$ \\
\hline VI & T & 1 & & $20 \mathrm{~h}$ at $420^{\circ} \mathrm{C}$ \\
\hline
\end{tabular}

\subsection{Reconstitution of cytochrome b5 monolayer}

Engineered cytochrome b5 was derived from human microsomal cytochrome b5 by genetic engineering resulting in the substitution of (i) the 26 C-terminal amino-acid residues by the NGHHHH-COOH sequence and (ii) the serine 23 in $\mathrm{Hb} 5(\mathrm{His})_{4}$ by cystein as previously described ${ }^{7}$. Modified human cytochrome b5 bears a unique cystein, i.e. a unique sulfhydryl residue, and is processed in saline phosphate buffer (PBS, $100 \mathrm{mM}$ at $\mathrm{pH} 7.4$ with $\mathrm{NaCl} 50 \mathrm{mM}$ ). Protein is reduced by a reducing agent in excess (dithiothreitol, DTT) (20/1 by moles) during $10 \mathrm{~min}$. Reduced cytochrome b5 $(20 \mu \mathrm{l}$ at $1 \mu \mathrm{M})$ is able to react directly by chemisorption onto gold substrate. During 15 min incubation, the reconstitution of a packed and oriented protein monolayer by direct selfassembly is obtained. A washing step by buffer first ( $20 \mu l 3$ times) and secondly by a detergent 
(Octylglucopyranoside (OG), $20 \mu \mathrm{l}$ at $40 \mathrm{mM}$ ) was realized after protein immobilization in order to remove not covalently bond proteins.

\subsection{AFM characterization}

The AFM used was a Nanoscope III (Veeco, Santa Barbara, CA). Imaging was performed in contact mode using NPS-oxide sharpened silicon nitride probes (Veeco). For the feedback controls, typical values of set-point for imaging were between 0.5 to $1.5 \mathrm{~V}$, depending on scan size.

\subsection{Image $J$ software}

We used Image $\mathbf{J}$ software to determine the area of gold terraces obtained on different substrates. 


\section{Results \& discussion}

We chose deposition of gold using electron beam evaporation method, since it offers possibility to work under elevated temperature until $300^{\circ} \mathrm{C}$ before, during and after the gold deposition. This temperature of $300^{\circ} \mathrm{C}$ corresponds to a transition structure of densely packed fibrous grains in Thornton diagram ${ }^{8}$ enabling to keep the state of mica's surface and to obtain the flat gold terraces. On this diagram, it is also possible to understand that evaporation with lower pressure and little energies of particles - i.e. less than $1 \mathrm{eV}$ - corresponds to a better solution than sputtering with a pressure of $5^{*} \times 10^{-3}$ mbar of argon and particles energies from 5 to $10 \mathrm{eV}$. According to Thornton diagram, it is important to choose evaporation conditions with lower pressure and a temperature $\mathrm{T} / \mathrm{Tm}$ in the range of 0,2 to 0,3 . T corresponds to the temperature of the condensation vapor, i.e. the temperature of the substrate, and $\mathrm{Tm}$ is the gold liquid temperature, i.e. $1063^{\circ} \mathrm{C}$.

According to the same Thornton diagram, it also means that with sputtering conditions the gold layer grew in columnar structure. The evaporation way with low deposition rate is the best one to form gold flat terraces. In the same field, the evaporation of gold with high speed was not chosen, because the roughness of the coating increased with the thickness and the flat terraces disappeared. The only way we found to better mimic the flatness of the mica substrate and obtain flat gold terraces, was evaporation beam with a temperature of $300^{\circ} \mathrm{C}$ and a pressure less than $5 * \times 10^{-5} \mathrm{mbar}$.

It appears that long bake-outs of the mica helped to outgas contamination which prevents direct stacking of Au atoms onto the mica surface ${ }^{9}$. We decided to use etching with neutral argon ion gun, in order to clean the surface without high particles energies and to avoid disturbance of the mica substrate.

\subsection{Morphology and size of terraces}

We have evaporated gold on pre-heated mica substrate and have tested different conditions of metal deposition and temperature. Different gold deposition rate, thickness and temperature conditions were 
experimented (Table 1). Indeed, the rate of metal deposition influences the roughness of the gold film. A classical evaporation without heating induces a rough gold film consisting of grains with a diameter around $30 \mathrm{~nm}^{4}$. While decreasing the gold deposition rate the surface topography gets smoother ${ }^{5}$. Thermal annealing of the evaporated films dramatically improves the flatness of the gold substrates, producing atomically flat terraces ${ }^{10,11}$.

For sample I, the gold thickness is $200 \mathrm{~nm}$ and only a short annealing time at $300^{\circ} \mathrm{C}(30 \mathrm{~min})$ is applied. Small terraces with irregular shape were obtained (Fig1A,B). The sample II was obtained after $50 \mathrm{~nm}$ gold deposition followed by a long annealing time at $300^{\circ} \mathrm{C}(8 \mathrm{~h})$. In this case, terraces present round shaped morphology (Fig1C,D). In the case of sample III and IV, $150 \mathrm{~nm}$ of gold were deposited but annealing time was $3 \mathrm{~h}$ or $20 \mathrm{~h}$ at $420^{\circ} \mathrm{C}$. In this last case, we obtained better results. Indeed, after $3 \mathrm{~h}$ annealing, terraces are larger than sample I and present an homogeneous shape, (Fig1E,F). After 20h annealing, the surface still presents these individual terraces, but several terraces seemed have fused together to give very large ones (Fig1G,H).

Concerning the size, we managed to prepare terraces from $22500 \mathrm{~nm}^{2}$ for sample I (Fig2A,D), to 55 $000 \mathrm{~nm}^{2}$ for sample III (Fig2B,D) and until more than $100000 \mathrm{~nm}^{2}$ (Fig2C,D) for sample IV. Thus, the tendency for the terraces to grow in size with annealing time appeared clearly (Fig2D).

Nevertheless, there is a maximum heating duration beyond which the gold surface is completely disorganized like "melt" on/with mica (sample V and Fig3A). AFM images do not present gold terraces anymore and the surface topography is a sort of intermediary between classical rough gold film and highly flat mica. Nogues and Wanunu (2004) $)^{12}$ also reported this phenomena, saying that overexposure (long time) of gold films to high temperatures had to be avoided. Indeed, when mica was heated to temperatures above $500{ }^{\circ} \mathrm{C}$, Derose et $\mathrm{al}^{9}$ remarked that the surface deteriorated becoming quite rough. It appears that the mica disintegrated at these temperatures causing poor epitaxy.

We also made two observations: first, there is a minimum gold thickness allowing preparation of relatively large terraces. Indeed, when only a deposition of $50 \mathrm{~nm}$ of gold is realized at $300^{\circ} \mathrm{C}$ (sample 
II), even followed by an annealing time of $8 \mathrm{~h}$ at $300^{\circ} \mathrm{C}$, small round and "donuts" shape terraces were obtained (Fig1C,D). Second, if the gold deposition is realized without heating the substrate, but followed by an annealing time at $420^{\circ} \mathrm{C}$ during several hours (sample VI), we did not succeed in gold terrace realization. The gold substrate presents in this case a rough surface presenting gold grains of around $30 \mathrm{~nm}$ in diameter (fig3B), that corresponds to the roughness of "classical" gold films.

Our work present then an easy way to prepare flat gold surfaces under highly controlled conditions of pressure and temperature. Moreover, this approach, using equipments in a "clean room", presents the advantage to protect the gold interface against contamination by polluting species in air. This last point is of deep importance when the substrate has to be efficiently and homogeneously functionalized by proteins for a biosensor development.

\subsection{Terraces flatness}

Higher resolution images revealed nicely individual gold terraces. These terraces are smooth on 100 (for the smallest) to $200 \mathrm{~nm}$ in length or more and present a maximum height variation of only around $5 \AA$ (Fig4). The morphology exhibited by such gold surfaces is therefore ideal for clear visualization, distinction and characterization of immobilized molecules and proteins.

\subsection{Visualization and counting of immobilized protein}

We developed flat surfaces in order to better characterize the protein monolayer immobilized at a gold surface. Indeed, classical evaporated gold films present a high roughness, with a surface composed of small grains in the same size range than proteins. The topography of such a rough surface prevents a clear visualization and characterization of a protein layer grafted on it. In our aim to characterize the reconstituted biomolecular film at the interface of sensor surface, the development of flat surface could allow to count individual molecules and determine their surface coverage, eventually their tridimensional structure and orientation. As a model, we worked with a protein containing a single 
cystein residue allowing its binding to gold. In Fig5 we show clearly the difference between before (Fig5A) and after (Fig5B) incubation of proteins on the gold terraces. Binding of proteins induced surface changes and appearance of lot of motifs on the gold surface. As a comparison, a classical evaporated gold film, without annealing, is represented before (Fig5C) and after (Fig5D) protein adsorption on the surface. Proteins are undistinguishable showing the difficulty to characterize the protein layer on this kind of rough surface. In opposite, on surface presenting terraces, proteins are visible, distinguishable and it is possible to control the density, homogeneity, to count proteins and

determine their surface coverage. We counted around 1200 proteins per $\mu \mathrm{m}^{2}$, meaning $1.210^{9}$ molecules $/ \mathrm{mm}^{2}$ thus $2 \mathrm{fmol} / \mathrm{mm}^{2}$. Aoyagi S. et al $(2008)^{2}$ mentioned that it is possible to perform SAMs with various density in a window of 1 to $200 \mathrm{fmol} / \mathrm{mm}^{2}$. Our AFM results then fit in this range. Images also revealed that the protein layer is homogeneous on gold surface, with proteins regularly distributed on the substrate. This AFM investigation revealed that neither particular concentration of molecules on sides of terraces nor aggregation of proteins appeared on the surface.

\section{Conclusion}

A new rapid, reproducible and highly controlled procedure for the preparation of clean flat gold terraces was presented. We demonstrated the usefulness of such flat surfaces for reconstitution of a protein monolayer and its easily characterization by AFM in terms of surface coverage, density and repartition of immobilized proteins. In order to use such flat gold surfaces in a biosensor, we are currently working on gold terraces formation on glass. With collaborators working on theoretical modeling of surface behavior, we are studying the ability of these flat surfaces to generate plasmons. This last development would open the way of these innovative atomically gold substrate investigation through their plasmon interrogation, giving informations on kinetics and mass loading. Thus, these flat gold surfaces could represent a really interesting flat and "active" substrate for biochip developments. 


\section{Acknowledgments}

We thank the centrale de technologie Mimento from FEMTO-ST institute in Besançon to have allowed realization of these different gold substrates.

\section{References}

1. R. Michel, D.G. Castner, Surf. Interface Anal. 38 (2006) 1386-1392.

2. Aoyagi S., Rouleau A., Boireau W. Applied Surface Science 255, (2008) 1071-1074.

3. D.J. Müller and Y.F. Dufresne, Nature Nanotechnology 3, (2008) 261-269.

4. T. Mangeat, A. Berthier, C. Elie Caille, M. Perrin, W. Boireau, C. Pieralli and B. Wacogne Laser physics 19, (2009) 252-58.

5. P. Samori, J. Diebel, H. Löwe, J.P. Rabe, Langmuir 19 (1999) 2592-2594

6. N.H. Thomson, B.L. Smith, N. Almqvist, L. Schmitt, M. Kashlev, E.T. Kool, P.K. Hansma, Biophysical Journal 76 (1999) 1024

7. W. Boireau, A. Duncan, D. Pompon, Meth. Mol. Biol. 300 (2005) 349-368

8. J.A. Thornton, J. Vac. Sci. Technol., 11(1974) 666

9. J.A. DeRose, T. Thundat, L.A. Nagahara and S.M. Lindsay. Surface Science 256 (1991) $102-$ 108.

10. S. Buchholz, H. Fuchs, J.P. Rabe, Journal of Vacuum Science \& Technology B 9 (1991) 857

11. M.H. Dishner, M.M. Ivey, S. Gorer, J.C. Hemminger, F.J. Feher, Journal of Vacuum Science \& Technology A- Vacuum Surfaces and Films 16 (1998) 3295.

12. C. Nogues, M. Wanunu, Surface Science 573 (2004) L383-L389 


\section{Figure legends}

Fig1: Gold terraces on mica obtained with different conditions of metal deposition rate, thickness and temperature. For each sample, a large scan (around $1 \mu \mathrm{m})$ and one zoom (around $500 \mathrm{~nm}$ ) are presented. (A,B) Sample I obtained with $200 \mathrm{~nm}$ gold deposited in two-steps: $150 \mathrm{~nm}$ at $5 \mathrm{~nm} / \mathrm{s}$ then $50 \mathrm{~nm}$ at $0.05 \mathrm{~nm} / \mathrm{s}$, followed by $30 \mathrm{~min} 300^{\circ} \mathrm{C}$ annealing. (C,D) Sample II obtained with $50 \mathrm{~nm}$ gold at $0,1 \mathrm{~nm} / \mathrm{s}$, followed by $8 \mathrm{~h} 300^{\circ} \mathrm{C}$ annealing. Sample III (E,F) obtained with $150 \mathrm{~nm}$ gold deposited at $0,1 \mathrm{~nm} / \mathrm{s}$ followed by $3 \mathrm{~h}$ annealing at $420^{\circ} \mathrm{C}$. Sample IV $(\mathrm{G}, \mathrm{H})$ obtained with $150 \mathrm{~nm}$ gold deposited at $0,1 \mathrm{~nm} / \mathrm{s}$ followed by $20 \mathrm{~h}$ at $420^{\circ} \mathrm{C}$. Scale bar: $100 \mathrm{~nm}$.

Fig2: Gold terrace areas of (A) sample I, (B) sample III and (C) sample IV. (D) Area of terraces function of annealing time. Scale bar: $100 \mathrm{~nm}$.

Fig3: Effect of heating during gold deposition and annealing time. (A) Gold surface after an annealing time of $32 \mathrm{~h}$ at $420^{\circ} \mathrm{C}$ (preheating of substrate at $300^{\circ} \mathrm{C}, 150 \mathrm{~nm}$ gold thickness at $300^{\circ} \mathrm{C}$ ). (B) Gold deposition without heating the substrate $\left(150 \mathrm{~nm}\right.$ gold thickness followed by annealing at $\left.420^{\circ} \mathrm{C} 20 \mathrm{~h}\right)$. Scale bar: $100 \mathrm{~nm}$.

Fig4: Flatness of individual gold terraces. (A) Gold terraces prepared with $50 \mathrm{~nm}$ gold evaporated at $0,1 \mathrm{~nm} / \mathrm{s}$, followed by $8 \mathrm{~h} 300^{\circ} \mathrm{C}$ annealing (sample II). (B) Cross-section along the white line in A. (C) Gold terraces prepared with $150 \mathrm{~nm}$ gold evaporated at $0,1 \mathrm{~nm} / \mathrm{s}$ followed by $3 \mathrm{~h}$ annealing (sample III). (D) Cross-section along the white line in B. (E) Gold terraces prepared with $150 \mathrm{~nm}$ gold at $0,1 \mathrm{~nm} / \mathrm{s}$ followed by $20 \mathrm{~h}$ at $420^{\circ} \mathrm{C}$ (sample IV). (F) Cross-section along the white line in E. Scale bar: $50 \mathrm{~nm}$.

Fig5: Gold terraces before (A) and after (B) cytochrome b5 immobilization. Comparison with a classical rough gold surface, before (C) and after (D) protein immobilization. Contact mode images in air, z scale $20 \mathrm{~nm}(\mathrm{~A}, \mathrm{~B})$ and $3 \mathrm{~nm}(\mathrm{C}, \mathrm{D})$. Scale bar: $100 \mathrm{~nm}$. 